\title{
The Effect of Curcumin on the Newborn Bone Development in Pregnant Rats that are Given Nicotine
}

\author{
Seher Yilmaz ${ }^{1 *}$,Ayșe Yeşim Göçmen² ${ }^{2}$ Adem Tokpinar ${ }^{1}$, Halil Yilmaz ${ }^{3}$, Mehtap Nisari ${ }^{4}$, Tolga \\ Ertekin $^{5}$, Şükrü Ateş ${ }^{1}$, Erdoğan Unur ${ }^{4}$ and Seda Avnioğlu ${ }^{6}$ \\ ${ }^{1}$ Department of Anatomy, YozgatBozok University Faculty of Medicine, Turkey \\ ${ }^{2}$ Department of Biochemistry, YozgatBozok University Faculty of Medicine, Turkey \\ ${ }^{3}$ Department of Therapy and Rehabilitation, Kozakli Vocational School, NevsehirHaciBektasVeli University, Turkey \\ ${ }^{4}$ Department of Anatomy, Erciyes University Faculty of Medicine, Turkey \\ ${ }^{5}$ Department of Anatomy, Afyonkarahisar Health Sciences University, Faculty of Medicine, Turkey \\ ${ }^{6}$ Alanya AlaaddinKeykubat University, Faculty of Medicine, Department of Anatomy, Turkey \\ *Corresponding author: Seher Yilmaz, Department of Anatomy, YozgatBozok University Faculty of Medicine, Turkey
}

\section{ARTICLE INFO}

Received: 蔧 August 25, 2020

Published: 幽 September 07, 2020

Citation: Seher Yilmaz, Ayșe Yeșim Göçmen, Adem Tokpinar, Halil Yilmaz, Mehtap Nisari, et al. The Effect of Curcumin on the Newborn Bone Development in Pregnant Rats that are Given Nicotine. Biomed J Sci \& Tech Res 30(1)-2020. BJSTR. MS.ID.004892.

Keywords: Bone, Curcumin,Nicotine, Oxidative Stress, Pregnant, Rat

\section{ABSTRACT}

Oxidative stress plays an important role in fetus development. In this study, the role of nicotine in skeletal system changes were investigated with double staining $6 \mathrm{mg} / \mathrm{kg}$ nicotine; and the protective role of 50 and $100 \mathrm{mg} / \mathrm{kg}$ curcumin was also investigated. Pregnant rats were divided into 6 groups with 5 rats in each. Nicotine was applied to the experimental groups and curcumin was applied to the treatment groups in addition to nicotine. The upper and lower extremities of the offspring were examined under a stereomicroscope ossification rates were calculated by using the ImageJ Program. Tumor Necrosis Factor alpha (TNF - $\alpha$ ), Interleukin 1ß (IL - 1ß), Interleukin 6 (IL - 6) levels were measured in tissue by using Enzyme-Linked ImmunoSorbent Assay method. Superoxide Dismutase (SOD), Glutathione (GSH), Glutathione disulfide (GSSG) Total Oxidant Status (TOS), Total Antioxidant Status (TAS), Calcium (Ca) and vitamin D (Vit D) measured by spectrophotometric assay. Oxidative Stress Index (OSI) and Total glutathione (GSH/GSSG) are useful indicators of oxidative stress tissues and were calculated as TOS-to-TAS and GSH-to-GSSG ratio respectively in the groups treated with curcumin were approximate to control group $(\mathrm{P}<0.05)$. IL - $1 \beta$ IL -6 and TNF- $\alpha$ values were notably higher in Nicotine group than in all the other groups. $(\mathrm{P}<0.05)$.

Abbreviations: TNF alpha: Tumor Necrosis Factor Alpha; SOD: Superoxide Dismutase; GSH: Glutathione; GSSG: Glutathione Disulfide; TOS: Total Oxidant Status; TAS: Total Antioxidant Status; Ca: Calcium; Vit D: vitamin D; OSI: Oxidative Stress Index; LDC: Low Dose Curcumin; HDC: High Dose Curcumin; ROS: Reactive Oxygen Species

\section{Introduction}

Smoking is now an important public health problem in all ountries and is one of the reasons for preventable deaths in many countries. Around 7 million people die due to smoking every year in the world [1]. The increase in female users causes more problems especially during pregnancy $[2,3]$. Smoking during pregnancy can cause low birth weight, respiratory diseases and cancer sensitivity in infants [4]. Nicotine is the most important toxic component of cigarette in offsprings. That inhibits the activity of osteoblasts increases osteoclast differentiation from osteocytes and reducing the mechanical strength of bone. Low birth weight and skeletal development deformations in rat pups due to nicotine use during pregnancy and lactation have been reported $[5,6]$. Various agents 
are used to prevent these teratogenic effects of Nicotine. The most frequently studied agents are natural antioxidants [7]. Previous studies have shown that curcumin is a powerful antioxidant and is used in some cancer studies because of its antioxidant properties and also supports bone development [8-10]. Today, various experimental studies are carried out to determine the effects of harmful substances on bone development; and one of these studies is the Double Skeleton Staining Method. The process of staining bone and cartilage structures with hdyes is called Double Skeleton Staining [7].

Studies in which double skeletal staining has been used are grouped into two as Teratogenic Studies and Developmental Studies. Teratogenic effects, skeletal system effects and morphological studies on fetuses have been carried out. The dual skeletal staining method on the skeletal system is frequently used $[7,11]$. Oxidative stress is a principal parameter for evaluating nicotine effect on rat bone [12]. Nicotine at high doses to cause miralizaton loss and loss of bone mechanical strength in intact rats. The results of the previous studies showed that nicotine is a risk factor for osteoporosis $[13,14]$. According to previous studies, curcumin has been shown to have inhibitory and delaying effects on the osteoporosis process. Studies have shown that patients with significant bone injury after 6 months in curcumin-treated groups have decreased osteoporosis progression and bone turnover markers [15]. Nicotine is a harmful chemical which injures bone at development stage. In this study hypothesized that curcumin could play critical role on normalizing oxidative and inflammatory parameters which upregulated by nicotine. Therefore, we aimed to evaluate the effect of Low Dose Curcumin (LDC) and High Dose Curcumin (HDC) on humerus bone tissue after investigated with nicotine.

\section{Material and Methods}

The present study was conducted in accordance with the decision of Local Ethics Committee of Animal Experiments, Erciyes University dated 15/11/2017 with the number 17/106. 30 Wistar - Albino rats weighing 220-240 g were obtained from Erciyes University Experimental Animal and Clinical Research Center. Rats were mated and vaginal smear test was performed. Female rats with sperm on the smear test were considered as 0.5 days pregnant.
During the experiment rats were kept at a constant temperature of $19-21^{\circ} \mathrm{C}$ and in a 12 hour light / dark environment. Experimental groups were formed through dividing pregnant rats into 6 groups. Invasive processes (1.p,s.c) were applied to the rats for 20 days during the pregnancy; and the gestational period lasted 21 days in average (Table 1).

Table 1: Creation of Experiment Groups.

\begin{tabular}{|c|c|c|}
\hline Experiment Groups & $\begin{array}{c}\text { Injection Days (Every } \\
\text { Day on Gestation Days) }\end{array}$ & Type of Injection \\
\hline Control & 20-Jan & i.p \\
\hline Nicotine $(6 \mathrm{mg} / \mathrm{kg})$ & 20-Jan & s.c \\
\hline $\begin{array}{c}\text { Low Dose }(50 \mathrm{mg} / \mathrm{kg}) \\
\text { Curcumin+Nicotine }\end{array}$ & 20-Jan & i.p+s.c \\
\hline $\begin{array}{c}\text { High Dose }(100 \mathrm{mg} / \mathrm{kg}) \\
\text { Curcumin+Nicotine }\end{array}$ & 20-Jan & i.p \\
\hline $\begin{array}{c}\text { Low Dose }(50 \mathrm{mg} / \mathrm{kg}) \\
\text { Curcumin }\end{array}$ & 20-Jan \\
\hline $\begin{array}{c}\text { High Dose }(100 \mathrm{mg} / \mathrm{kg}) \\
\text { Curcumin }\end{array}$ & 20-Jan & i.p \\
\hline
\end{tabular}

\section{Dissolution and Sterilization of Curcumin and Nicotine}

Nicotine and Curcumin were obtained from Sigma-Aldrich. PBS (Phosphate Buffer Saline) was used as a solvent for nicotine. Curcumin was dissolved in different volumes to provide the desired concentrations for each experimental group with DMSO (dimethyl sulfoxide) and PBS buffer. The DMSO ratio was adjusted to $0.05 \%$ of the total solution, the resulting solution was diluted with PBS; and the solutions prepared daily were sterilized by filtration.

\section{Manipulation of Offspring}

The offspring which were born were taken under Ketamine (75 mg / kg) + Xylazine (10 mg / kg) anesthesia. After cleaning the abdomen regions of the offspring with $70 \%$ alcohol, the abdominal walls were removed with a transverse incision, internal organs were removed, and the offspring were subjected to the Double Skeletal Staining Method (Table 2). For morphometric measurements, the images of the offspring were taken with Nikon E5700 camera via a stereomicroscope and were transferred to the computer. The length and area measurements of the bones in the images were measured using the Image J Program.

Table 2: Double staining method in neonatal bone.

\begin{tabular}{|c|c|c|}
\hline Technical Stages & Solutions & Time \\
\hline Fixation & $70 \%$ ethyl alcohol & 4-7 days \\
\hline Degreasing & Pure acetone & 1-3 days \\
\hline \multirow{5}{*}{ Double Satining } & preparing the double staining solution & 7 days \\
\hline & $\mathbf{1}^{\text {st }}$ solution: $300 \mathrm{mg}$ Alcian Blue $+100 \mathrm{ml} 70 \%$ ethyl alcohol & $38-40{ }^{\circ} \mathrm{C}$ incubated \\
\hline & $2^{\text {nd }}$ solution: $100 \mathrm{mg}$ Alizarin Red $\mathrm{S}+100 \mathrm{ml} 95 \%$ ethyl alcohol & \\
\hline & $3^{\text {th }}$ solution: $1^{\text {st }}$ solution $+2^{\text {nd }}$ Solution $+100 \mathrm{ml}$ Glacial acetic acid & \\
\hline & $\begin{array}{c}4^{\text {th }} \text { solution: Prepared by adding } 1700 \mathrm{ml} \text { of } 70 \% \text { ethyl alcohol to the first three soluti- } \\
\text { ons. }\end{array}$ & \\
\hline
\end{tabular}




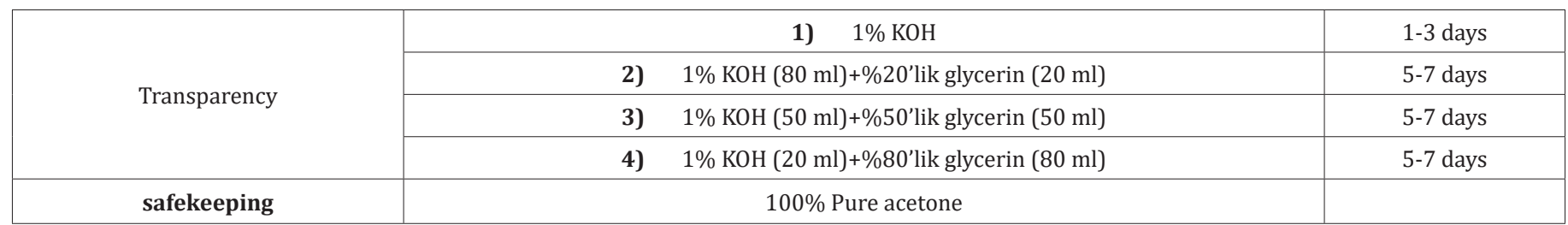

\section{Biochemical Analysis}

Tissue Preparation and Protein Quantification: Humerus used for analysis and placed into microcentrifuge tubes than washed 3x with $1 \mathrm{~mL} 100 \mathrm{mM}$ PBS and aspirated. Stainless steel beads (1.6 mm blend) used for homogenization with $100 \mathrm{mM}$ PBS. After homogenization, homogenates were centrifuged at 10.000 RPM for 30 minutes at $+4^{\circ} \mathrm{C}$. Supernatant was used as protein samples. Protein content was assayed using the BioRAD DC Protein Assay (BioRAD, 5000116).

Oxidative Stress Parameters: Oxidative stress parameters including TAS, TOS and SOD levels were determined by spectrophotometry. Tissue TAS level was determined by Erel, 2004 An antioxidant with a known concentration ( $1.65 \mathrm{mmol} / \mathrm{l})$ was used as the standard to calculate antioxidant levels in the samples. The TAS level was expressed as mmol Trolox equivalent/l (mmol Trolox equiv./ l) [16]. The tissue TOS level was measured by Erel, 2005 The assay was calibrated with a standard hydrogen peroxide solution (39.16 $\mu \mathrm{mol} / \mathrm{l})$. Results were expressed as $\mu \mathrm{mol} \mathrm{H}_{2} \mathrm{O}_{2}$ equivalent / $\mathrm{l}\left(\mu \mathrm{mol} \mathrm{H}_{2} \mathrm{O}_{2}\right.$ equiv./l) [17]. Other oxidative stress parameters such as GSH (Cat. No: EIAGSHC, Thermo Fisher, USA), GSSG (Cat. No: a 703002, Cayman, USA) and SOD (Cat. E-BC - K020, Elabscience, USA) performed by using spectrophotometer (Multiskan, Thermo Fisher) according to manufacturer's instructions. Vitamin D analysis was determined using the commercial ELISA kit (EIA 539 DRG, Germany).

\section{Inflammation Parameters and $\mathrm{Ca}^{+2}$}

Protein samples were thawed, and commercial ELISA kits were used for the quantitative measurement of TNF - $\alpha$ (Cat. No: E - EL - R0019, Elabscience USA), IL-1ß (Cat. No: E-EL-R0012, Elabscience USA), IL - 6 (Cat. No: E-EL-R0015, Elabscience USA) levels, according to the manufacturer's instructions. Results are expressed in milligram per milliliter of proteins. ELISA was performed with protein samples extracted from tissues, according to the manufacturer's instructions. Total $\mathrm{Ca}^{+2}$ concentration was evaluated by using calcium colorimetric assay kit (ab102505; Abcam) according to the manufacturer's datasheet. $25 \mu \mathrm{L}$ of standard solution and $25 \mu \mathrm{L}$ of supernatant extracted from tissue, diluted $1: 10$, were mixed with $45 \mu \mathrm{L}$ of chromogenic reagent and $30 \mu \mathrm{L}$ assay buffer. The mixture was incubated at room temperature for 15 minutes in the dark. The signal was screened at $575 \mathrm{~nm}$ (Thermo Varioscan). The concentration of calcium in the samples was calculated according to [18].

\section{Statistical Analysis}

All analyses were conducted using SPSS version 23.0 (IBM Co., NY, USA). Data were presented as the mean \pm standard deviation. For analysis of the differences in continuous variables among the groups, data were analyzed using one-way analysis of variance (ANOVA) followed by the post hoc Tukey's test for parametric data and the Kruskal - Wallis test followed by the post hoc Dunn's test for nonparametric data. Statistical significance was defined as a two-tailed $\mathrm{P}<0.05$.

\section{Results}

\section{Effects on Upper Extremity Long Bones}

In study, long bones (humerus, radius, ulna) of the upper extremities were evaluated. Generally, when $6 \mathrm{mg} / \mathrm{kg}$ nicotine was given, there was a statistically significant decrease in the region lengths and ossification percentages, which showed the ossification in these bones $(\mathrm{P}<0.05)$ When the additional curcumin was given, it was determined that the ossification increased and approached to that of the Control Group (Figure 1), (Table 3).

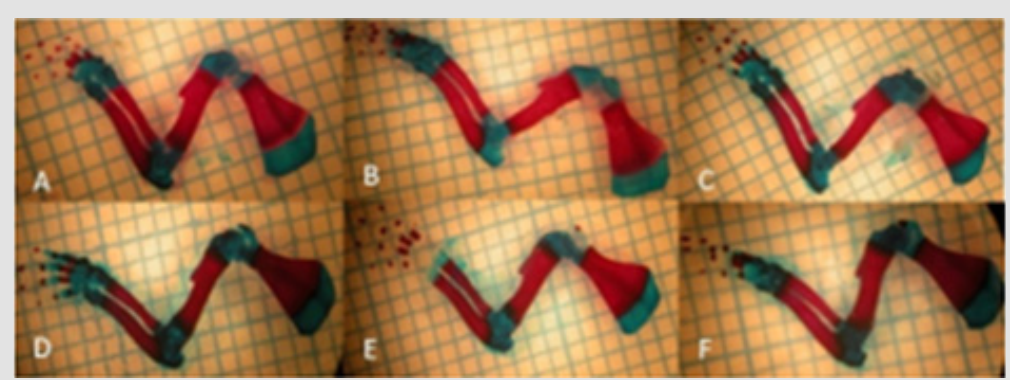

Figure 1: Images of the upper extremity bones bones: (A) Control group; (B) Low-dose (50mg/kg) Curcumin group; (C) High-dose (100 mg/kg) Curcumin group; (D) Nicotine+ Low-dose Curcumin; (E) Nicotine+ High-dose Curcumin group; (F) Nicotine group 
Table 3: Upper extremity long bones (Ossification rate).

\begin{tabular}{|c|c|c|c|c|c|c|c|c|c|c|}
\hline & & \multicolumn{3}{|c|}{ Humerus } & \multicolumn{3}{|c|}{ Radius } & \multicolumn{3}{|c|}{ Ulna } \\
\hline & $\mathbf{N}$ & $\begin{array}{c}\text { Total } \\
\text { bone } \\
\text { Length }\end{array}$ & $\begin{array}{c}\text { Length of } \\
\text { Ossified } \\
\text { Part }\end{array}$ & $\begin{array}{c}\text { Ossification } \\
\text { Rate(\%) }\end{array}$ & $\begin{array}{c}\text { Total } \\
\text { bone } \\
\text { Length }\end{array}$ & $\begin{array}{c}\text { Length of } \\
\text { Ossified } \\
\text { Part }\end{array}$ & $\begin{array}{c}\text { Ossification } \\
\text { Rate(\%) }\end{array}$ & $\begin{array}{l}\text { Total bone } \\
\text { Length }\end{array}$ & $\begin{array}{l}\text { Length of } \\
\text { Ossified } \\
\text { Part }\end{array}$ & $\begin{array}{c}\text { Ossification } \\
\text { Rate(\%) }\end{array}$ \\
\hline Control & 30 & 6.95 & 3.6 & $52.17 \pm 3.24$ & 5.09 & 3.23 & $61.49 \pm 5.14$ & 6,17 & 4.16 & $61.59 \pm 5.38$ \\
\hline Nicotine & 30 & 6.79 & 3.07 & $43.99 \pm 2.93^{\mathrm{a}, \mathrm{b}, \mathrm{c}, \mathrm{d}, \mathrm{e}}$ & 4.94 & 3.04 & $\underset{\mathrm{a}, \mathrm{b}, \mathrm{c}, \mathrm{d}}{51.86 \pm 4.83}$ & 5.99 & 3.01 & $52.63 \pm 3.91^{\mathrm{a}, \mathrm{b}, \mathrm{c}, \mathrm{d}, \mathrm{e}}$ \\
\hline N+LDC & 30 & 6.92 & 3.18 & $47.91 \pm 3.03^{a, b, c, d}$ & 4.97 & 3.09 & $\underset{\mathrm{a}, \mathrm{b}, \mathrm{c}, \mathrm{d}}{54.28 \pm 4.82}$ & 6.1 & 3.37 & $59.87 \pm 4.06^{\mathrm{a}, \mathrm{b}, \mathrm{c}}$ \\
\hline $\mathrm{N}+\mathrm{HDC}$ & 30 & 6,91 & 3.66 & $52,04 \pm 4.44$ & 5.05 & 3.24 & $60.85 \pm 4,28$ & 6.09 & 4.19 & $61.49 \pm 5.81$ \\
\hline LDC & 30 & 6.89 & 3.64 & $52.87 \pm 3.19$ & 5.11 & 3.21 & $61.12 \pm 4.06$ & 6.22 & 4.14 & $62.50 \pm 4.86$ \\
\hline HDC & 30 & 6.95 & 3.69 & $53.17 \pm 4.73$ & 5.14 & 3.25 & $61.27 \pm 4.37$ & 6.29 & 4.21 & $64.35 \pm 5.64$ \\
\hline
\end{tabular}

Note: ANOVA test $\mathrm{P}<0.05$ was considered statistically significant;N:Nicotine; HDC: high dose curcumin;LDC:low dose curcumin. a) It is significant when compared with the control group. b) It is significant when compared with the HDC group. c) It is significant when compared with the LDC group. d) It is significant when compared with the N+HDC group. e) It is significant when compared with the N+LDC group.

\section{Effects on Lower Extremity Long Bones}

In study, long bones of the lower extremity (femur, tibia and fibula) were also evaluated. A statistically significant decrease was found in the percentage of ossification in only the nicotinetreated group $(\mathrm{P}<0.05)$. It was determined that ossification was more likely to reach the values of the Control Group in additional

Table 4: Lower extremity long bones (Ossification rate). curcumin to nicotine and curcumin groups (Figure 2), (Table 4). In our study, the average offspring size was lower in the groups to which nicotine was administered compared to the control group and to the group to which curcumin was administered. There were dead births in the groups to which nicotine was administered; and it was determined that maternal food consumption decreased in the nicotine-administered group (Table 5).

\begin{tabular}{|c|c|c|c|c|c|c|c|c|c|c|}
\hline & & \multicolumn{3}{|c|}{ Femur } & \multicolumn{3}{c|}{ Tibia } & \multicolumn{3}{c|}{ Fibula } \\
\cline { 2 - 13 } & $\mathbf{N}$ & $\begin{array}{c}\text { Total bone } \\
\text { Length }\end{array}$ & $\begin{array}{c}\text { Length of } \\
\text { Ossified } \\
\text { Part }\end{array}$ & $\begin{array}{c}\text { Ossification } \\
\text { Rate(\%) }\end{array}$ & $\begin{array}{c}\text { Total } \\
\text { bone } \\
\text { Length }\end{array}$ & $\begin{array}{c}\text { Length of } \\
\text { Ossified Part }\end{array}$ & $\begin{array}{c}\text { Ossification } \\
\text { Rate(\%) }\end{array}$ & $\begin{array}{c}\text { Total } \\
\text { bone } \\
\text { Length }\end{array}$ & $\begin{array}{c}\text { Length of } \\
\text { Ossified } \\
\text { Part }\end{array}$ & $\begin{array}{c}\text { Ossification } \\
\text { Rate(\%) }\end{array}$ \\
\hline Control & 30 & 6,32 & 3,09 & $49,84 \pm 3.23$ & 5.93 & 3,13 & $49,66 \pm 3.56$ & 5,62 & 3,23 & $44,33 \pm 4.84$ \\
\hline Nicotine & 30 & 6.08 & 2.47 & $40.73 \pm 4.18^{\mathrm{a}, \mathrm{a}, \mathrm{c}, \mathrm{d}}$ & 5.65 & 2.27 & $39.13 \pm 3.52^{\mathrm{a}, \mathrm{b}, \mathrm{c}, \mathrm{d}, \mathrm{e}}$ & 5.2 & 1.83 & $34.96 \pm 3.33^{\mathrm{a}, \mathrm{b}, \mathrm{c}, \mathrm{d}, \mathrm{e}}$ \\
\hline N+LDC & 30 & 6.13 & 3 & $43.14 \pm 4.43^{\mathrm{a}, \mathrm{b}, \mathrm{c}, \mathrm{d}}$ & 5.77 & 2.73 & $44.08 \pm 4.09^{\mathrm{a}, \mathrm{b}, \mathrm{c}, \mathrm{d}}$ & 5.3 & 2.29 & $39.77 \pm 4.29$ a,b,c,d, \\
\hline N+HDC & 30 & 6.26 & 3.04 & $48.51 \pm 4.87$ & 5.89 & 3.07 & $48.58 \pm 4.08$ & 5.63 & 3.19 & $44.71 \pm 4.34$ \\
\hline $\mathbf{5 0}$ LDC & 30 & 6.29 & 3.14 & $48.63 \pm 4.26$ & 5.93 & 3.14 & $49.89 \pm 4.62$ & 5.67 & 3.24 & $46.67 \pm 4.22$ \\
\hline $\mathbf{1 0 0}$ HDC & 30 & 6.23 & 3.1 & $47.06 \pm 3.28$ & 5.59 & 3.1 & $49.73 \pm 4.70$ & 5.65 & 3.21 & $46.09 \pm 3.84$ \\
\hline
\end{tabular}

Note: ANOVA test $\mathrm{P}<0.05$ was considered statistically significant;N:Nicotine; HDC: high dose curcumin;LDC:low dose curcumin.

a) It is significant when compared with the control group. b) It is significant when compared with the HDC group.c) It is significant when compared with the LDC group. d) It is significant when compared with the N+HDC group. e) It is significant when compared with the N+LDC group.

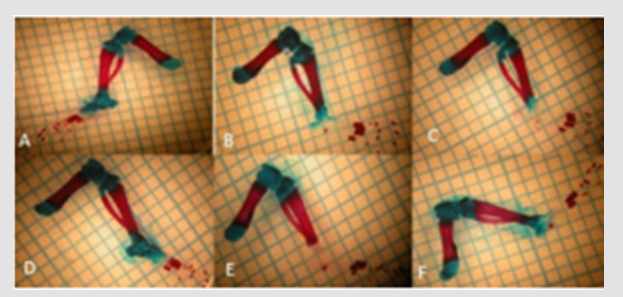

Figure 2: Images of the lower extremity bones bones: (A) Control group. (B) Low-dose (50mg/kg) Curcumin group. (C) Highdose $(100 \mathrm{mg} / \mathrm{kg})$ Curcumin group. (D)Nicotine+ Low-dose Curcumin group (E) Nicotine+ High-dose Curcumin group. (F) Nicotine group. 
Table 5: Maternal mortality and food consumption rates during pregnancy. Offspring macroscopic data.

\begin{tabular}{|c|c|c|c|c|c|c|}
\hline & \multirow{2}{*}{ Control } & \multirow{2}{*}{ Nicotine $6 \mathrm{mg} / \mathrm{kg}$} & $\mathrm{N}+\mathrm{LDC}$ & $\mathrm{N}+\mathrm{HDC}$ & \multirow{2}{*}{$\begin{array}{l}\text { Curcumin } \\
50 \mathrm{mg} / \mathrm{kg}\end{array}$} & Curcumin \\
\hline & & & $50 \mathrm{mg} / \mathrm{kg}$ & $100 \mathrm{mg} / \mathrm{kg}$ & & $100 \mathrm{mg} / \mathrm{kg}$ \\
\hline Gestation food consumption (g/animal/day) & 15 & 13.3 & 13.9 & 14.2 & 14.2 & 14.7 \\
\hline Number of live fetuses for each maternal & $12 \pm 3.2$ & $11 \pm 2.6$ & $11 \pm 3.2$ & $11 \pm 3.3$ & $12 \pm 1.7$ & $12 \pm 3.4$ \\
\hline Maternal mortality & 0 & 1 & 1 & 0 & 0 & 0 \\
\hline \multicolumn{7}{|c|}{ Macroscopic malformations in newborn } \\
\hline Soft tissue & 0 & 3 & 2 & 0 & 0 & 0 \\
\hline Skeletal & 0 & 1 & 0 & 1 & 0 & 0 \\
\hline Rudimentary tail & 0 & 1 & 0 & 0 & 0 & 0 \\
\hline
\end{tabular}

Biochemical Assay Results (Assessment of Oxidative

\section{Stress Parameters)}

The highest TAS value obtained at Control group whereas the lowest TOS value obtained at Nicotine group. Curcumin administration increased antioxidant status significantly in a dose dependent manner when compared with Nicotine group. Dose dependent curcumin showed more antioxidant effect while used without nicotine (Figure 3). TOS values showed that the highest oxidant effect observed at Nicotine group. Control group has the lowest value (Figure 4). Oxidative stress index was calculated as ratio of TOS and TAS. OSI in Nicotine group considerably higher than the other groups (Figure 3). OSI decreased in curcumin administrated groups. In Nicotine group SOD has highest value compared to the other groups. Dose dependent curcumin with nicotine has lower value than curcumin without nicotine. Vitamin D showed inversed effect while comparing with SOD. In Control group Vitamin D has highest value than the other groups (Figure 4). GSH and GSH/GSSG has highest value in control group whereas GSSG has highest value in nicotine group. Curcumin increased GSH and GSH/GSSG values while decreased GSSG values comparing nicotine and control groups respectively (Figure 5). According to these results curcumin markedly decreased oxidative stress via stimulating antioxidant system.
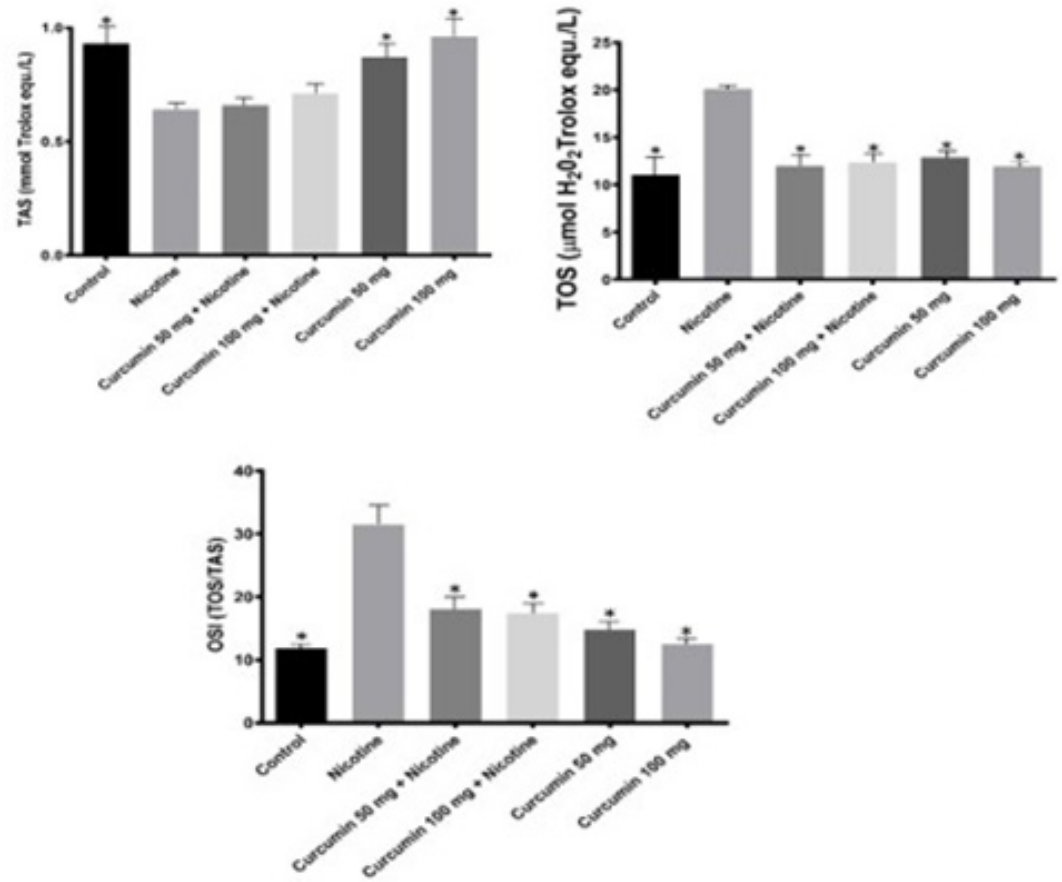

Figure 3: Mean TAS, TOS and OSI levels in all groups. The data are expressed as mean \pm standard deviation $\left({ }^{*} \mathrm{P}<0.05\right.$ vs. Nicotine group. One way ANOVA, post hoc Tukey test). 


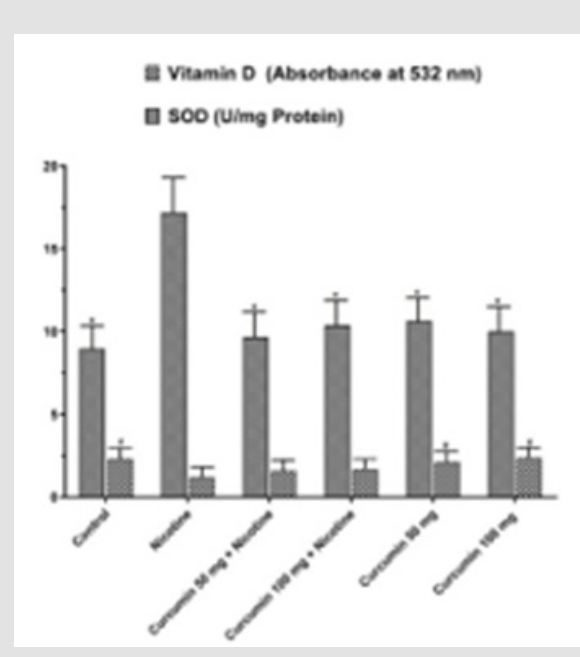

Figure 4: Mean Vitamin D and SOD levels in all groups. The data are expressed as mean \pm standard deviation $\left({ }^{*} \mathrm{P}<\right.$ 0.01 vs. Nicotine group. \#P $<0.05$ vs. Nicotine group. One way ANOVA, post hoc Tukey test).

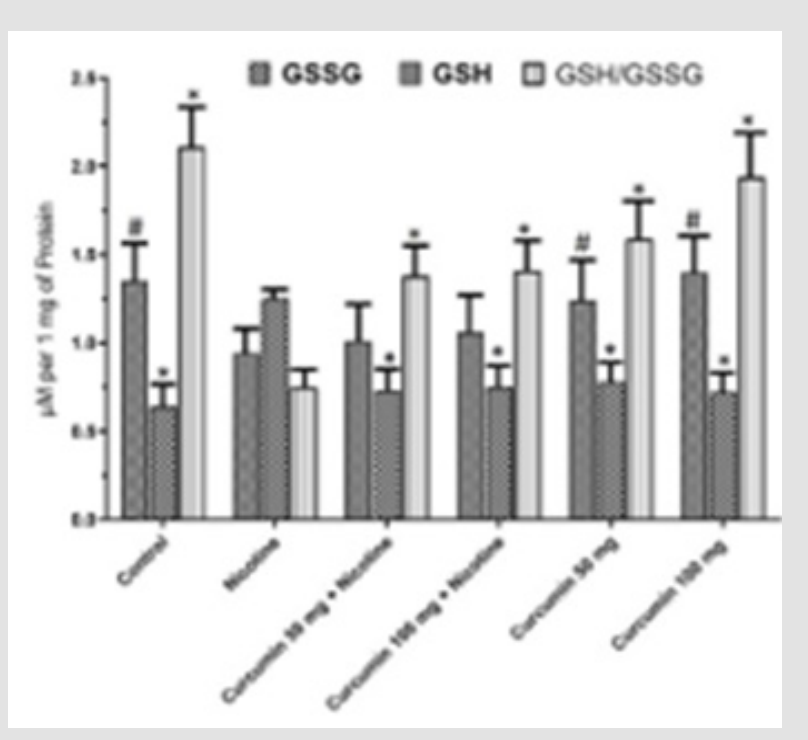

Figure 5: Mean GSSG, GSH and GSH/GSSH levels in all groups. The data are expressed as mean \pm standard deviation $\left({ }^{*} \mathrm{P}<0.05\right.$ vs. Nicotine group, $\# \mathrm{P}<0.01$ vs. Nicotine group. One way ANOVA, post hoc Tukey test).

\section{Assessment of Inflammatory and Calcium Parameters}

IL - $1 \beta$ IL - 6 and TNF - $\alpha$ values were notably higher in Nicotine group than in all the other groups. Dose depended curcumin with nicotine groups has higher value than dose depended curcumin without nicotine (Figure 6) Curcumin particularly showed an antiinflammatory effect against nicotine via reducing tissue levels of IL - $1 ß$ IL - 6 and TNF - $\alpha$. In Nicotine group intracellular calcium value has the highest level. Nicotine treatment following dose depended curcumin administration increased calcium level slightly whereas curcumin administrated groups without nicotine treatment have higher value (Figure 7).

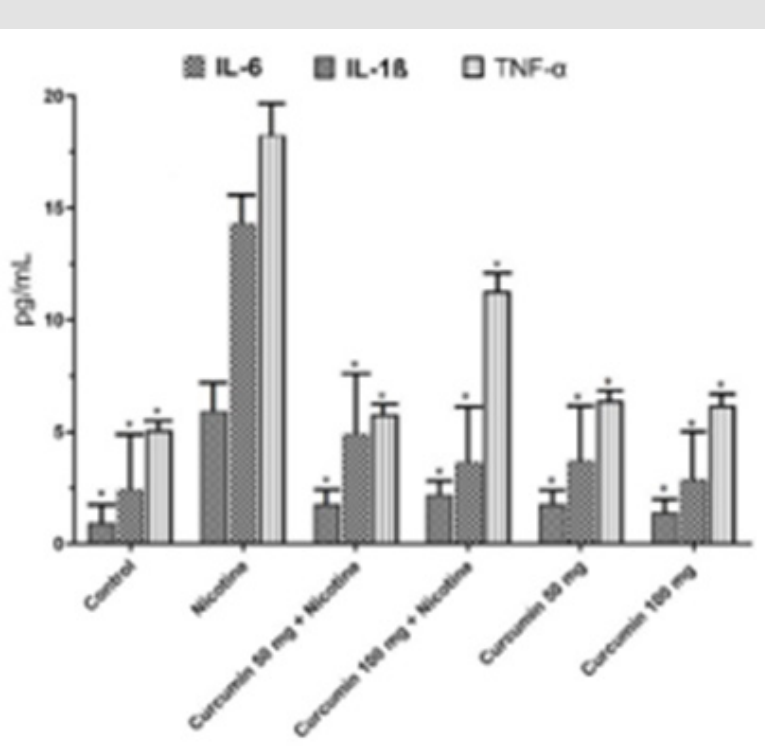

Figure 6: Mean IL-6, IL-1ß, TNF-a levels in all groups. The data are expressed as mean \pm standard deviation $(* P<0.01$ vs. Nicotine group. One way ANOVA, post hoc Tukey test).

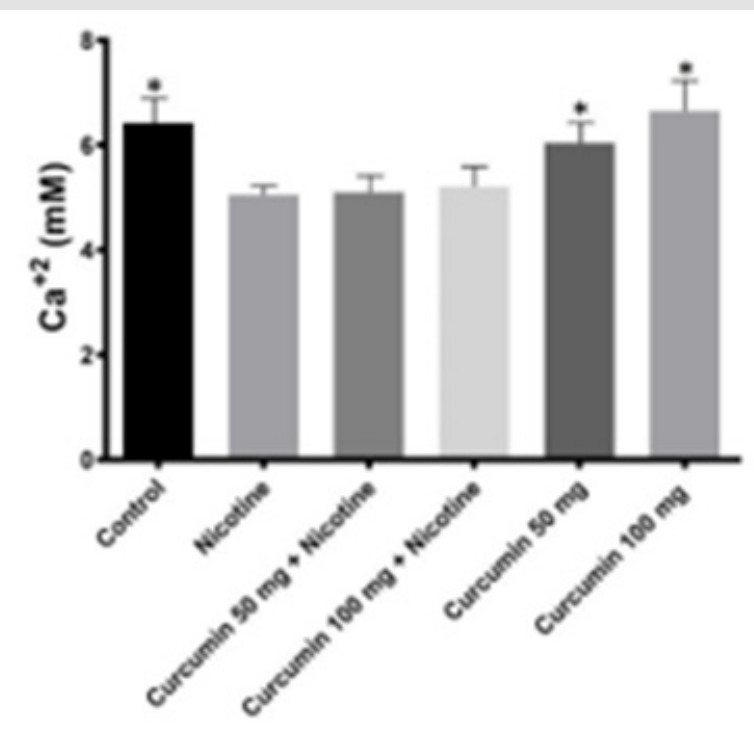

Figure 7: Intracellular Calcium levels in all groups. The data are expressed as mean \pm standard deviation $\left({ }^{*} \mathrm{P}<0.05\right.$ vs. Nicotine group. One way ANOVA, post hoc Tukey test).

\section{Discussion}

Nicotine easily passes through the placenta due to its lipophilic nature. Several researchers used different doses of nicotine in rats during pregnancy in their experimental studies. In the literature, these doses range from $1.67 \mathrm{mg} / \mathrm{kg}$ to $7.5 \mathrm{mg} / \mathrm{kg}$. [7,19,20]. investigated the protective effects of melatonin against the effects of nicotine on bones in their study; and found that the percentage 
and rate of ossification was low in the upper and lower extremity bones of the group to which $6 \mathrm{mg} / \mathrm{kg}$ nicotine was administered $(31.42 \pm 10.33)$ compared to the control group $(43.71 \pm 2.33)$. In their study, they stated that this ratio was close to the Control Group in the melatonin group [7,21]. investigated the negative effects of nicotine on bone development. In their study, they administered 3 $\mathrm{mg} / \mathrm{kg}$ nicotine given i.p. during pregnancy and lactation. At the end of the experiment, it was reported that femur lengths of 21 days old offspring in the group treated with nicotine $(19.1 \pm 1.6 \mathrm{~mm})$ were significantly lower than the control group $(21.1 \pm 0.3)$ and in their study they shown maternal nicotine exposure resulted in decreased birth weight, pregnancy weight gain, and bone lengthening, and increased apoptosis [21]. The lactation period of the mothers who smoked was measured for 24 hours in the study of [22], which were evaluated as $113 \pm 179 \mathrm{ml}$ in the Control Group and $47 \pm 122 \mathrm{ml}$ in the group in which mothers smoked [22,23].injected $2 \mathrm{mg} / \mathrm{kg}$ nicotine s.c into pregnant rats in their studies; and determined the dose of $2 \mathrm{mg} / \mathrm{kg}$ nicotine as 12 cigarettes per day. In their study, they reported that total cholesterol values in mother serum were higher than controls [23,24]. studied the teratogenic effect of nicotine in female fetuses exposed to cigarette smoke for 14 days before pregnancy and for 20 days during pregnancy, and male rats that were exposed to cigarette smoke for 28 days before pregnancy. In rats exposed to $18.6 \pm 2.07 \mathrm{mg} / \mathrm{m}^{3}$ Nicotine and $600 \mathrm{mg}, 41.8 \pm$ $3.71 \mathrm{mg} / \mathrm{m}^{3}$, a significant increase was reported in the number of missing or non-ossified bones in rats exposed to nicotine $[24,25]$ evaluated the osteoclast genesis and endochondral ossification of long bones of fetuses in pregnant rats exposed to nicotine. In their study, they used $2 \mathrm{mg} / \mathrm{kg}$ nicotine s.c for 20 days in pregnant rats.

As a result of their experiments, they reported a significant decrease in the length of femur in fetuses exposed to nicotine compared to control group [25]. There are many studies conducted on pregnant rats and individuals showing that nicotine causes a decrease in fetus ossification rate. In the literature, this effect has been reported to be reduced by means of various antioxidant agents [3]. One of these substances is curcumin. Curcumin is used as a colorant in spices, food and textiles, and in diets, as well as in many diseases [26]. Many different pharmacological activities and biological benefits of Curcumin have attracted considerable attention in recent years [27]. Many studies have shown that Curcumin has anti-oxidant, anti-carcinogen, anti-inflammatory, anti-allergic, anti-dementia effects and is a free radical scavenger [28-30]. gave $30 \mathrm{mg} / \mathrm{kg}$ curcumin to the rats treated with periodontitis and reported that alveolar ossification increased [28,29].investigated the effect of curcumin on glucocorticoid-induced osteoporosis in rats and reported that curcumin increased osteoblast activity and decreased osteoclast activity [29,30], applied 50,100, $200 \mathrm{mg} / \mathrm{kg}$ curcumin as a gavage for 30 days to heal Benzo [a] pyrene-induced DNA damage in stomach tissues [31]. In the study, it was stated that curcumin reduced the negative effect of nicotine on neonatal skeletal development and values approached the control group. Experimental studies on animals or cultured human cell lines support a role of polyphenols in the prevention of cardiovascular diseases, cancers, neurodegenerative diseases, diabetes, or osteoporosis [32]. When bone fractures occur, a remarkably high yield of radicals is generated. It is suggested that as a break occurs, the minimal crystallites separate at grain boundaries with no major chemical changes, but the tightly bound collagen strands running through the mineral phase are forced to break homiletically. Some react with oxygen and yield oxygen radical metabolites [33]. Cigarette smoke is a complex mixture of more than 4700 chemical compounds including free radicals and oxidants. Toxicity exhibited by cigarette smoke may be due to combined action of these compounds inducing many cellular processes mediated through Reactive Oxygen Species (ROS). Major player probably nicotine as it is present in tobacco, in higher concentrations. Meanwhile, elevated levels of ROS can damage proteins, lipids, and DNA, eventually trigger oxidative stress and leading to cell death [34,35]. Oxidative damage to bio-macromolecule has been proved in the etiology of a wide variety of acute and chronic diseases, including osteoporosis [36].

Measurement of TOS, TAS, Vitamin D and SOD is a crucial biomarker to evaluate oxidative damage [37-41]. In this study we detected that curcumin increased the TAS level whereas decreased the TOS levels both nicotine threated groups and nicotine untreated groups. The highest value of SOD was observed in Nicotine group and as well as the lowest value was recorded at control group. Nicotine significantly increased SOD level by stimulating reactive oxygen system thus as an antioxidant curcumin slightly decrease the effect of nicotine and approximate the values to control group. Vitamin D is an antioxidant ant it decreases when cell damaged [42]. In Nicotine group Vitamin D has the lowest value and Control group has the highest value. After nicotine treatment due to the ROS activity Vitamin D level significantly decreased but after dose dependent curcumin treatment it increased slightly.

GSH, present in concentrations of $2-10 \mathrm{mM}$ within cells, is the primary determinant of the cellular redox environment and exists mainly as the biologically active reduced-thiol form [43]. The oxidation of GSH to GSSG and subsequent decrease in the GSH/GSSG ratio is often associated with oxidative stress. Thus, the GSH/GSSG ratio is a simple and useful indicator of cellular redox state $[44,45]$. In the current study GSH decreased by the effect of the nicotine while curcumin treatment values approximated to Control group. Likewise, GSH/GSSG showed same attitude but GSSG values were observed as just the opposite. Inflammatory responses observe after necrotic cell death. Nicotine induces necrosis following inflammation. Inflammatory markers have been widely used to show inflammation situation such as IL-6, IL-1 $\beta$ and TNF- $\alpha$. The serum concentrations of those markers increase after nicotine 
treatment $[46,47]$. In the current study IL-6, IL-1 $\beta$ and TNF- $\alpha$ levels in Nicotine group were markedly increased in rats. Previous studies showed that curcumin treatment act as anti-inflammatory agent $[48,49]$. In present study curcumin showed alike anti-inflammatory effect in opposition to Nicotine in all curcumin treated groups through reducing levels of IL-6, IL-1 $\beta$ and TNF- $\alpha$.

Intracellular calcium signaling controls scores basic cellular processes including proliferation, differentiation, and cellular motility [50]. Calcium levels are conserved at very low concentrations intracellularly via its removal to the extracellular environment and sequestration in the endoplasmic reticulum. As such, it is a powerful second messenger important in proliferation, differentiation, mitosis, and motility. In bone cells, an extracellular influx and intracellular release is rapidly activated by strain, pressure, and fluid flow [51-53]. In the current study Nicotine group has the lowest Calcium level. After nicotine treatment following curcumin administration calcium level slightly increased while dose dependent curcumin treatment groups has highest calcium level. Thus, we suggest that curcumin is effective in reducing oxidative stress and bone lose induced by nicotine in rats.

\section{Conclusion}

As a result of our study, it was determined that there was a decrease in bone development and decrease in ossification rate in fetuses of pregnant rats exposed to nicotine. Different doses of curcumin were given to the rats against nicotine, and it was determined that the number of non-ossified bones decreased, and normal development was observed in bone development, especially in the high-dose curcumin-treated groups. As a conclusion curcumin therapy after nicotine administration markedly improved anatomical and biochemical findings and prohibited oxidative stress and inflammation. According to these data we propose that curcumin at the 100 and $150 \mathrm{mg}$ may be used as a potential therapeutic agent to prevent bone lose induced by nicotine and our results will be beneficial in model studies which will be conducted on curcumin and nicotine.

\section{References}

1. Bolat F, Eren Ö, Bolat G, Can E, Cömert S, et al. (2012) Maternal smoking during pregnancy and effects on neonatal anthropometry: a prospective study. Turkish Journal of Medical Sciences 42(6): 999-1005.

2. Banderali G, Martelli A, Landi M, Moretti F, Betti F, et al. (2015) Short and long term health effects of parental tobacco smoking during pregnancy and lactation: a descriptive review. Journal of translational medicine 13(1): 1-7.

3. Mahabady MK, Varzi HN, Jahromi SZ (2015) L-Carnitine protect against cyclophosphamide induced skeletal and neural tube malformations in rat fetuses. Acta Medica Iranica pp. 703-710.

4. Chou HC, Chen CM (2014) Maternal nicotine exposure during gestation and lactation induces cardiac remodeling in rat offspring. Reproductive Toxicology 50: 4-10.

5. Benowitz NL, Hukkanen J, Jacob P (2009) Nicotine chemistry, metabolism, kinetics and biomarkers. In Nicotine psychopharmacology 192: $29-60$.
6. Norazlina M, Lee PL, Lukman HI, Nazrun AS, Ima-Nirwana S (2007) Effects of vitamin E supplementation on bone metabolism in nicotinetreated rats. Singapore medical journal 48(3): 195-199.

7. Yllmaz H, Ertekin T, Atay E, Nisari M, Güler HS, et al. (2018) Antioxidant role of melatonin against nicotine's teratogenic effects on embryonic bone development. Iranian journal of basic medical sciences 21(8): 787 793.

8. Kocaadam B, Şanlier N (2017) Curcumin, an active component of turmeric (Curcuma longa), and its effects on health. Critical reviews in food science and nutrition 57(13): 2889-2895.

9. Hatcher H, Planalp R, Cho J, Torti FM, Torti SV (2008) Curcumin: from ancient medicine to current clinical trials. Cellular and molecular life sciences 65(11): 1631-1652.

10. Thakam A, Saewan N (2011) Antioxidant activities of curcumin-metal complexes. Thai Journal of Agricultural Science 44(5 Special Issue): 188193

11. Soysal H, Unur E, Düzler A, Karaca Ö, Ekinci N (2011) Effects of intraperitoneal administration of the phenytoin on the skeletal system of rat fetus. Seizure 20(3): 187-193.

12. Jensen K, Nizamutdinov D, Guerrier M, Afroze S, Dostal D, et al. (2012) General mechanisms of nicotine-induced fibrogenesis. The FASEB journal 26(12): 4778-4787.

13. Daffner SD, Karnes JM, Watkins CM (2016) Surgeon specialty influences referral rate for osteoporosis management following vertebral compression fractures. Global spine journal 6(6): 524-528.

14. Turan V, Mizrak S, Yurekli B, Yilmaz C, Ercan G (2013) The effect of longterm nicotine exposure on bone mineral density and oxidative stress in female Swiss Albino rats. Archives of gynecology and obstetrics 287(2): 281-287.

15. Hatefi M, Ahmadi MR H, Rahmani A, Dastjerdi MM, Asadollahi K (2018) Effects of curcumin on bone loss and biochemical markers of bone turnover in patients with spinal cord injury. World neurosurgery 114 : e785-e791.

16. Erel 0 (2004) A novel automated direct measurement method for total antioxidant capacity using a new generation, more stable ABTS radical cation. Clinical biochemistry 37(4): 277-285.

17. Erel $O$ (2005) A new automated colorimetric method for measuring total oxidant status. Clinical biochemistry 38(12): 1103-1111.

18. Sen KS, Duarte Campos DF, Köpf M, Blaeser A, Fischer H (2018) The effect of addition of calcium phosphate particles to hydrogel-based composite materials on stiffness and differentiation of mesenchymal stromal cells toward osteogenesis. Advanced healthcare materials 7(18): 1800343

19. Gunes T, Akin MA, Canoz O, Coban D, Ozcan B, et al. (2011) Aortic intimamedia thickness in nicotine-exposed rat pups during gestation and lactation period. European journal of pediatrics 170(10): 1257-1262.

20. Tizabi Y, Russell LT, Nespor SM, Perry DC, Grunberg NE (2000) Prenatal nicotine exposure: effects on locomotor activity and central [125I] $\alpha$-BT binding in rats. Pharmacology Biochemistry and Behavior 66(3): 495500 .

21. Kurtoglu S, Gunes T, Koklu E, Bastug O, Canoz O, et al. (2007) Influence of maternal nicotine exposure on neonatal rat bone: protective effect of pentoxifylline. Experimental Biology and Medicine 232(3): 398-405.

22. Hopkinson JM, Schanler RJ, Fraley JK, Garza C (1992) Milk production by mothers of premature infants: influence of cigarette smoking. Pediatrics 90(6): 934-938

23. Zhang G, Zhou J, Huang W, Yu L, Zhang Y, et al. (2018) Placental mechanism of prenatal nicotine exposure-reduced blood cholesterol levels in female fetal rats. Toxicology letters 296: 31-38.

24. Carmines EL, Gaworski CL, Faqi AS, Rajendran N (2003) In utero exposure to $1 \mathrm{R} 4 \mathrm{~F}$ reference cigarette smoke: evaluation of developmental toxicity. Toxicological Sciences 75(1): 134-147. 
25. Hu H, Zhao X, Ma J, Shangguan Y, Pan Z, et al. (2018) Prenatal nicotine exposure retards osteoclastogenesis and endochondral ossification in fetal long bones in rats. Toxicology Letters 295: 249-255.

26. Chan MM Y (1995) Inhibition of tumor necrosis factor by curcumin, a phytochemical. Biochemical pharmacology 49(11): 1551-1556.

27. Chen HW, Huang HC (1998) Effect of curcumin on cell cycle progression and apoptosis in vascular smooth muscle cells. British journal of pharmacology 124(6): 1029-1040.

28. Xiao CJ, Yu XJ, Xie JL, Liu S, Li S (2018) Protective effect and related mechanisms of curcumin in rat experimental periodontitis. Head \& face medicine 14(1): 1-8.

29. Chen Z, Xue J, Shen T, Mu S, Fu Q (2016) Curcumin alleviates glucocorticoid-induced osteoporosis through the regulation of the Wnt signaling pathway. International journal of molecular medicine 37(2): 329-338.

30. Limtrakul P, Lipigorngoson S, Namwong O, Apisariyakul A, Dunn FW (1997) Inhibitory effect of dietary curcumin on skin carcinogenesis in mice. Cancer letters 116(2): 197-203.

31. Kim KS, Kim NY, Son JY, Park JH, Lee SH, et al. (2019) Curcumin Ameliorates Benzo [a] pyrene-Induced DNA Damages in Stomach Tissues of Sprague-Dawley Rats. International journal of molecular sciences 20(22): 5533

32. Scalbert A, Manach C, Morand C, Rémésy C, Jiménez L (2005) Dietary polyphenols and the prevention of diseases. Critical reviews in food science and nutrition 45(4): 287-306.

33. Tveden NP, Bergmann TK, Lykkesfeldt J (2018) Toxicology policy for experimental and clinical studies. Basic \& clinical pharmacology, Toxicology 123(3): 233-235.

34. Glasauer A, Chandel NS (2013) Ros Current Biology 23: 100-102.

35. Valko M, Leibfritz D, Moncol J, Cronin MT, Mazur M, et al. (2007) Free radicals and antioxidants in normal physiological functions and human disease. The international journal of biochemistry \& cell biology 39(1): 44-84.

36. De Boer J, Andressoo JO, De Wit J, Huijmans J, Beems RB, et al. (2002) Premature aging in mice deficient in DNA repair and transcription. Science 296(5571): 1276-1279.

37. Altintas O, Kumas M, Altintas MO (2016) Neuroprotective effect of ischemic preconditioning via modulating the expression of adropin and oxidative markers against transient cerebral ischemia in diabetic rats. Peptides 79: 31-38.

38. Prakash R, Li W, Qu Z, Johnson MA, Fagan SC, et al. (2013) Vascularization pattern after ischemic stroke is different in control versus diabetic rats: relevance to stroke recovery. Stroke 44(10): 2875-2882.

39. Gariballa SE, Hutchin TP, Sinclair AJ (2002) Antioxidant capacity after acute ischaemic stroke. Qjm 95(10): 685-690.

\section{ISSN: 2574-1241}

DOI: $10.26717 /$ BJSTR.2020.30.004892

Seher Yilmaz. Biomed J Sci \& Tech Res

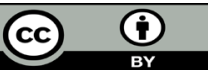

This work is licensed under Creative

Commons Attribution 4.0 License

Submission Link: https://biomedres.us/submit-manuscript.php
40. Tagliaferri S, Porri D, De Giuseppe R, Manuelli M, Alessio F, et al. (2019) The controversial role of vitamin $\mathrm{D}$ as an antioxidant: results from randomised controlled trials. Nutrition research reviews 32(1): 99-105.

41. Mc Cord JM, Edeas MA (2005). SOD, oxidative stress and human pathologies: a brief history and a future vision 59(4):139-42.

42. Halicka HD, Zhao H, Li J, Traganos F, Studzinski GP, et al.(2012) Attenuation of constitutive DNA damage signaling by 1, 25-dihydroxyvitamin D3. Aging (Albany NY) 4(4): 270-278.

43. Biswas SK, Rahman I (2009) Environmental toxicity, redox signaling and lung inflammation: The role of glutathione. Molecular aspects of medicine 30(1-2): 60-76.

44. Romagnoli C, Marcucci G, Favilli F, Zonefrati R, Mavilia C, et al. (2013) Role of GSH/GSSG redox couple in osteogenic activity and osteoclastogenic markers of human osteoblast-like Sa OS-2 cells. The FEBS journal 280(3): 867-879.

45. Jones DP (2002) Redox potential of GSH/GSSG couple: Assay and biological significance. In Methods in enzymology 348: 93-112.

46. Alkhattabi N, Todd I, Negm O, Tighe PJ, Fairclough LC (2018) Tobacco smoke and nicotine suppress expression of activating signaling molecules in human dendritic cells. Toxicology letters 299: 40-46.

47. Westerlund A, Björklund U, Rönnbäck L, Hansson E (2013) Long-term nicotine treatment suppresses IL-1 $\beta$ release and attenuates substance P-and 5-HT-evoked $\mathrm{Ca}^{2+}$ responses in astrocytes. Neuroscience Letters 553: 191-195.

48. Aggarwal BB, Surh YJ, Shishodia S (2007) The molecular targets and therapeutic uses of curcumin in health and disease. Springer Science \& Business Media.

49. Qian J, Chen X, Shu S, Zhang W, Fang B, (2019) Design and synthesis novel di-carbonyl analogs of curcumin (DACs) act as potent anti-inflammatory agents against LPS-induced Acute Lung Injury (ALI). European journal of medicinal chemistry 167: 414-425.

50. Berridge MJ, Lipp P, Bootman MD (2000) The versatility and universality of calcium signalling. Nature reviews Molecular cell biology 1(1): 11-21.

51. You J, Yellowley CE, Donahue HJ, Zhang Y, Chen Q, et al. (2000) Substrate deformation levels associated with routine physical activity are less stimulatory to bone cells relative to loading-induced oscillatory fluid flow. J Biomech Eng 122(4): 387-393.

52. You J, Reilly GC, Zhen X, Yellowley CE, Chen Q et al. (2001) Osteopontin gene regulation by oscillatory fluid flow via intracellular calcium mobilization and activation of mitogen-activated protein kinase in MC3T3-E1 osteoblasts. Journal of Biological Chemistry 276(16): 1336513371.

53. Khayyeri H, Checa S, Tägil M, Prendergast PJ (2009) Corroboration of mechanobiological simulations of tissue differentiation in an in vivo bone chamber using a lattice-modeling approach. Journal of Orthopaedic Research 27(12): 1659-1666.

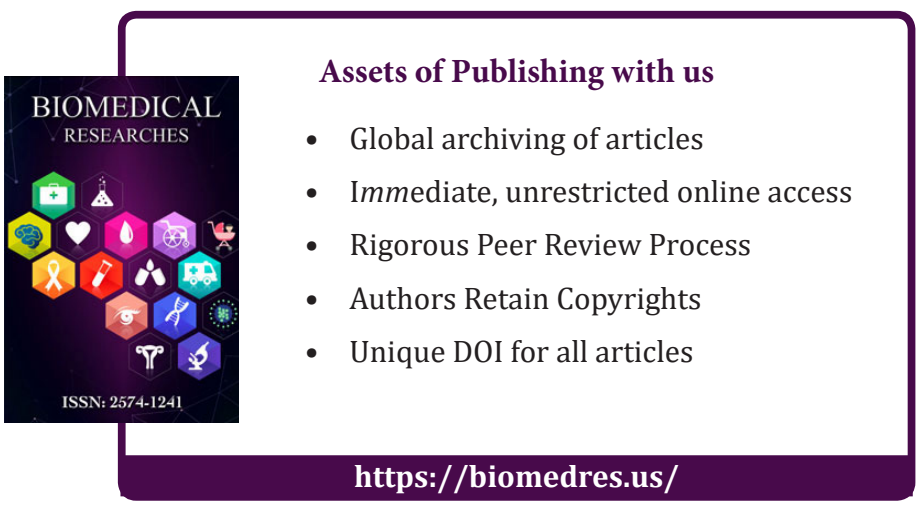

Copyright@ Seher Yilmaz | Biomed J Sci \& Tech Res | BJSTR. MS.ID.004892. 